\title{
Jual Beli Produk Tupperware Bergaransi Seumur Hidup Menurut Hukum Islam
}

\author{
Ayu Darnis, Bahrul Maani dan Pidayan Sasnifa \\ Fakultas Syari'ah IAIN Sulthan Thaha Saifuddin Jambi \\ E-mail: bahrulmaani@gmail.com
}

\begin{abstract}
This study aims to determine the perspective of Islamic law regarding the implementation of the system of buying and selling tupperware products that have a lifetime guarantee at PT. Nazila Jambi Nugraha Simpang Kawat, Jambi City. Another purpose of the research is to find out the positive impact of this system for sellers and buyers of tupperware products. Using a qualitative approach with data collection methods through interviews, documentation, and observation, the results of the study found: first, the distributor company has given books or catalogs to retail sellers or resellers as well as members or members to sell these products at prices listed for each product. Distributors give a discount of $30 \%$ for the resseller or member. Second, the view of Islamic law on the sale and purchase of tupperware products that are guaranteed, according to Islamic law there is still an element of openness regarding providing a lifetime guarantee. In the contract there must be openness between the two parties to avoid the existence of elements of fraud. Third, the positive impact on sellers and buyers is equally beneficial. For sellers to benefit and add friendship, buyers get the benefits of tupperware products.
\end{abstract}

Keywords: lifetime warranty; Tupperware; Islamic law.

\begin{abstract}
Abstrak: Penelitian ini bertujuan untuk mengetahui perspektif hukum Islam tentang pelaksanaan sistem jual beli produk tupperware yang bergaransi seumur hidup di PT. Nazila Jambi Nugraha Simpang Kawat, Kota Jambi. Tujuan lain penelitian adalah untuk mengetahui dampak positif sistem ini bagi penjual dan pembeli produk tupperware. Menggunakan pendekatan kualitatif dengan metode pengumpulan data melalui wawancara, dokumentasi, dan observasi, hasil penelitian menemukan: pertama, perusahaan distributor telah memberi buku atau katalog kepada penjual eceran atau reseller sekaligus member atau anggota untuk menjual produk tersebut dengan harga yang telah dicantumkan masing-masing produk. Distributor memberikan potongan harga sebesar 30\% untuk resseller atau member. Kedua, pandangan hukum Islam terhadap jual beli produk tupperware yang bergaransi, masih terdapat unsur ketidakterbukaan mengenai pemberian garansi seumur hidup. Ketiga, dampak positif bagi penjual dan pembeli adalah sama-sama menguntungkan. Bagi penjual mendapat keuntungan dan menambah silaturahmi, bagi pembeli mendapatkan manfaat dari produk tupperware.
\end{abstract}

Kata-kata kunci: jual beli; Tupperware; Hukum Islam.

\section{Pendahuluan}

Persaingan usaha yang semakin ketat diera yang serba modern ini, membuat pengusaha harus menciptakan layanan yang inovatif, hal ini demi meningkatkan penjualan produknya, salah satunya adalah dengan memberikan layanan garansi sesuai dengan pasal 7 huruf e UU No 8 Tahun 1999 tentang perlindungan konsumen disebutkan bahwa pelaku usaha berkewajiban memberikan jaminan atau garansi atas barang yang diperdagangkan ${ }^{1}$. KUHPerdata tentang perikatan

1Pasal 7 UU Nomor 8 Tahun 1999 Tentang Perlindungan Konsumen. 
pasal 1491 bahwa : Penanggungan yang menjadi kewajiban penjual terhadap pembeli, adalah untuk menjamin dua hal yaitu pertama, dank e dua Penguasaan barang yang dijual itu secara aman dan tentram dan Tiadanya cacat tersembunyi pada barang tersebut, atau yang sedemikian rupa sehingga menimbulkan alasan untuk pembatalan pembelian. ${ }^{2}$

Pasal 1504 yang berbunyi: Penjual harus menanggung barang itu terhadap cacat tersembunyi, yang sedemikian rupa sehingga barang itu tidak dapat digunakan untuk tujuan yang dimaksud, atau yang demikian mengurangi pemakaian, pembeli mengetahui cacat pada barang tersebut, barang itu tidak akan dibeli kecuali dibeli denganharga yang lebih murah. Garansi adalah suatu perjanjian kontraktual yang mengharuskan produsen untuk memperbaiki atau mengganti produk yang mengalami kerusakan selama masa garansi, adanya garansi menunjukkan keunggulanan dan kualitas dari sebuah produk dan garansi merupakan salah satu bentuk pelayanan yang di berikan penjual kepada pembeli terhadap hak pembeli. Garansi dapat dipandang sebagai kewajiban berdasarkan perjanjian dan yang diadakan oleh produsen dalam hubungannya dengan penjualan produk, perjanjian tersebut menentukan kualitas produk apakah sesuai dengan yang dijanjikan atau tidak, sehingga ganti rugi harus disediakan oleh produsen bagi konsumen sebagai kompensasi atas perfomansiyang tidak sesuai atau terjadi kerusakan.

Secara umum garansi bertujuan memberi perlindungan pada konsumen apabila produk tidak sesuai dengan yang diinginkan. Konsumen maupun produsen mendapat mamfaat garansi bagi konsumen garansi melindungi agar terhindar dari pembelian produk yang cacat. Bagi produsen garansi membatasi klaim yang tidak rasional dari konsumen, disamping itu konsumen dapat memamfaatkan garansi sebagai alat promosi yang efektif karena produk dengan masa garansi lebih lama memberi sinyal kepada konsumen bahwa produk tersebut memiliki kualitas yang lebih baik. ${ }^{3}$ Garansi seumur hidup adalah garansi penuh dari produsen bahwa produsen akan memperbaiki atau mengganti barang yang menjadi objek jual beli karena adanya cacat atau kerusakan pada barang yang dijual tanpa biaya.

Indonesia adalah salah satu negara yang warganya menjalankan bisnis atau usaha dengan menciptakan sebuah produk dan menambahkan label garansi , pada saat ini produk yang menggunakan label garansi sangat banyak terutama produk elektronik, hampir semua produk elektronik mempunyai label garansi, akan tetapi bagaimana jika label garansi itu diberikan pada produk plastik seperti alat-alat rumah tangga. Salah satu produk plastik yang menyelenggarakan garansi seumur hidup adalah tupperware. Tupperware merupakan produk plastik berkualitas untuk keperluan rumah tangga, tupperware pertama kali muncul di Indonesia pada tahun 1991 oleh PT. Alif Rose di Jakarta dan merupakan distributor resmi dari tupperware. Jadi konsumen dapat mengajukan klaim tanpa batasan waktu selama produk tersebut masih ada atau diproduksi dengantetapmengikuti prosedur dan persyaratan yang berlaku. Contoh, apabila suatu produk yang bergaransi seumur hiduphingga lima tahun kedepan masih diproduksi oleh pabrik, maka produk terebut akan terus digaransi. Akan tetapi adakah pabrik yang memproduksi barang yang sama dengan kurun waktu lima tahun. Biasanya dalam

2Soedharyono Soimin, Kitab Undang-Undang Hukum Perdata, cet. ke-9, (Jakarta: Sinar Grafika, 2010), hlm.362.

${ }^{3}$ Ummy Salamah, Tinjauan Hukum Islam Terhadap Garansi DalamJual Beli, (Yogyakarta: Fakultas Syriah IAIN Sunankalijaga 2006) hlm. 45. 
waktu dua atau tiga tahun suatu produk sudah tidak diproduksi lagi dan sudah diganti dengan produk yang lebih inovatif dengan teknologi dan harga yang lebih tinggi karena untuk memenuhi persaingan pasar, pabrik pasti akan memproduksi barang dengan bentuk dan model yang lebih menarik.

Pada umumnya setiap pembelian produk bergaransi, pasti konsumen akan mendapatkan kartu garansi. Kartu garansi garansi bertujuan sebagai bentuk surat perjanjian tertulis yang mana memuat beberapa ketentuan garansi dan jangka waktu berakhirnya garansi. Selain itu kartu garansi juga berfungsi sebagai cacatan perjanjian, bahwa produsen menjamin garansi pada konsumen yaitu garansi seumur hidup. Perjanjian yang memuat beberapa ketentuan ini dibuat secara sepihak oleh produsen sehingga konsumen tidak dapat menawar lagi. ${ }^{4}$

Akan tetapi berbeda hal nya dengan yang dilakukan oleh PT. Nazila Jambi Nugraha,setiap orang yang menjadi member atau konsumen dari tupperware ketika membeli produk tupperware tidak mendapatkan kartu garansi. Bahkan di setiap produk tupperware tidak disertakan label garansi yang menunjukan bahwa produk itu mempunyai garansi seumur hidup atau tidak.Informasi mengenai garansi seumur hidup tupperware hanya bisa dilihat melalui website saja. Padahal dalam hal akad ketika bertransaksi harus ada transparansi dan asas kerelaan kedua belah pihak. Sedangkan dalam transaksi ini agen tidak menunjukan perjanjian garansi seumur hidup yang jelas pada konsumen, sehingga tidak sedikit dari konsumen tupperware tidak mengetahui apakah produk yang diklaim tersebut mempunyai garansi seumur hidup atau tidak, karena beberapa produk tidak mendapatkan garansi seperti dalam ketentuan garansi tuppeware.

Berdasarkan permasalahan di PT. Nazila Jambi Nugraha bahwa dalam bertransaksi harus ada transparansi dan suka rela kedua belah pihak. Hal ini telah dijelas dalam Al-Quran Surat An-Nissa ayat 29.

"Hai orang-orang yang beriman, janganlah kamu saling memakan harta sesamamu dengan jalan yang batil, kecuali dengan jalan perniagaan yang berlaku dengan suka sama-suka di antara kamu. Dan janganlah kamu membunuh dirimu; sesungguhnya Allah adalah Maha Penyayang kepadamu". 5

Pendekatan penelitian adalah hukum Islam dengan metode kualitatif. Pengumpulan data melalui wawancara, dokumentasi dan observasi. Wawancara dilakukan dengan pihak distributor, PT. Nazila Jambi Nugraha, selain itu penulis juga mewawancarai tiga karyawan, dan para konsumen. ${ }^{6}$

\section{Jual Beli Produk dan Landasan Hukumnya}

Jual beli adalah suatu perjanjian tukar menukar benda atau barang yang mempunyai nilai secara suka rela diantara kedua belah pihak, yang satu menerima benda dan pihak lain menerima sesuai dengan perjanjian atau ketentuan yang telah dibenarkan syara'. Adapun jual beli beli menurut istilah syara'ialah saling menukar harta dengan harta lainnya dengan cara tertentu atau menukar harta dengan harta yang lainnya yang dapat dikembangkan setelah adanya dengan cara

\footnotetext{
4Taufiq Hidayat, Garansi dan Penerapannya..., hlm.46.

${ }^{5}$ An- Nisa (68) : 29.

${ }^{6}$ Ibid., hlm. 145.
} 
yang telah diatur, landasan hukum jual beli ini ialah Al-Quran, As-sunah, Ijma' dan Qiyas. ${ }^{7}$

Para ulama berbeda pendapat dalam mendefisikan, antara lain: Menurut Ulama Hanafiyah adalah Pertukaran harta benda dengan harta berdasarkan cara khusus; Menurut Imam Nawawi dalam Al-majmu', yaitu Pertukaran harta dengan harta untuk kepemilikan, dan Menurut Ibnu Qudamah Pertukaran harta dengan harta , untuk saling menjadikan milik. ${ }^{8}$ Menurut Al-Qur'an, jual beli adalah:

"Orang-orang yang makan mengambil riba tidak dapat berdiri melainkan seperti berdirinya orang yang kemasukan syaitan lantaran tekanan penyakit gila. Keadaan mereka yang demikian itu, adalah disebabkan mereka berkata, sesungguhnya jual beli itu sama dengan riba, padahal Allah telah menghalalkan jual beli dan mengharamkan riba. Orang-orang yang telah sampai kepadanya larangan dari Tuhannya, lalu terus berhenti dari mengambil riba, maka baginya apa yang telah diambilnya dahulu sebelum datang larangan, dan urusannya terserah kepada Allah. Orang yang kembali mengambil riba, maka orang itu adalah penghuni-penghuni neraka mereka kekal di dalamnya". ${ }^{9}$

Berdasar hadits Rasullah SAW ditanya salah satu sahabat mengenai pekerjaan (profesi) apa paling baik. Rasullah SAW menjawab: Usaha tangan manusia sendiri dan setiap jual beli yang yang diberkati ". (HR. Al-Bazzardan AlHakim). ${ }^{10}$ Kegiatan jual beliterus mengalami perkembangan seiring dengan perkembangan Islam, maka proses jual beli di beberapa daerah yang berbeda tentu akan menimbulkan perbedaan pendapat. Oleh karena itulah, Ijma ulama dan ahli fikih juga mendasari pembenaran atas bentuk jual beli yang beraneka ragam. Jika menimbulkan perkara yang menyebabkan masalah di kemudian hari serta tidak melanggar hukum dasar jual beli , maka jual beli menjadi boleh dilakukan. Para ulama telah sepakat bahwa jual beli di perbolehkan dengan alasan bahwa manusia memang sangat membutuhkan dan tidak akan mampu mencukupi kebutuhan dirinya, tanpa bantuan orang lain. Namun Demikian bantuan atau barang milik orang lain yang membutuhkan nya itu, harus diganti dengan barang lainnya yang sesuai. ${ }^{11}$ Berdasarkan Qiyas analogi hukum dilihat dari satu sisi bahwa kebutuhan manusia memerlukan hadirnya suatu proses transaksi jual beli. Hal ini disebabkan karena kebutuhan manusia sangat bergantung pada sesuatu yang ada dalam milik saudaranya. Sudah tentu saudaranya tersebut tidak akan memberikan begitu saja tanpa diganti, dari sini tampak lah hikmah diperbolehkannya jual beli agar manusia dapat memenuhi tujuannya sesuai yang diinginkan. ${ }^{12}$

Jual beli adalah untuk mengatur individu dalam melaksanakan aktifitas ekonomi dan tanpa disadari secara spontanitas akan terikat oleh kewajiban dan hak terhadap sesama pelaku ekonomi yang sama semua itu berdasarkan atas ketentuan Al-Qur'an dan Hadist sebagai pedoman dalam ajaran Islam. Dengan jual beli , maka interaksi dalam dunia muamalah manusia akan teratur, masing-masing

7Wahbah Zuhaili, Fiqih Imam Syafi'i , Mengupas Masalah fiqhiyah berdasarkan Al-Quran dan Hadist, (Jakarta : Al-Mahira, 2010), hlm. 617.

${ }^{8}$ Rahmad Syafei, Fiqh Muamalah, ( Bandung: Pustaka Setia, 2000), hlm 73-74.

${ }^{9}$ Q.S. Al-Baqarah (2) : 275.

${ }^{10} \mathrm{Al}-\mathrm{Bazzar}$ dan Al- Hakim akses 28 Oktober 2015.

${ }^{11}$ Ibid., hlm 75.

12Wahbah Zuhaili, Fiqih Imam..., hlm. 45. 
individu dapat mencari rezeki dengan aman dan tenang tanpa ada rasa khawatir terhadap suatu kemungkinan yang tidak diinginkan.Hal tersebut dapat terwujud bila jual beli tersebut sesuai dengan ketentuan hukum yang berlaku yang melindungi tentang kewajiban dan hak yang melekat pada setiap individu.

Menurut jumhur ulama jual beli ada empat macam yaitu: Adanya orang yang berakad atau penjual dan pembeli; Ada shighat atau lapal Ijab dan Qabul; Ada barang yang dibeli; dan ada nilai tukar pengganti barang. ${ }^{13}$ Adapun syarat-syarat jual beli sesuai dengan rukun jual beli yang dikemukan jumhur ulama diatas sebagai berikut: Syarat- syarat orang yang berakal, ada penjual dan pembeli dan Ijab dan Qabul. Jual beli dapat ditinjau dari beberapa segi hukum nya ada dua macam yaitu jual beli yang sah menurut hukum dan batal menurut hukum, dari segi objek jual beli dan segi pelaku jual beli. Jual beli ada tiga macam yaitu Jual beli benda yang kelihatan, Jual beli yang disebutkan sifat-sifat nya dalam janji, Jual beli yang tidak ada. Jual beli yang kelihatan ialah pada waktu ,melakukan akad jual beli benda atau barang yang diperjualbelikan ada didepan penjual dan pembeli. Jual beli dengan sifat-sifatnya dalam perjanjian ialah jual beli salam menurut kebiasaan para pedagang salam adalah untuk jual beli yang tidak tunai ,salam pada awalnya bearti meminjamkan barang atau sesuatu yang seimbang dengan harga tertentu. Maksudnya ialah perjanjian yang penyerahan barang-barang nya ditangguhkan hingga masa tertentu, sebagai imbalan harga yang telah ditetapkan ketika akad. ${ }^{14}$ Jual beli benda yang tidak ada serta tidak dapat dilihat ialah jual beli yang dilarang oleh agama Islam karena barangnya tidak tentu atau masih gelap sehingga dikhawatirkan barang tersebut diperoleh dari curian atau barang titipan yang akibatnya dapat menimbulkan kerugian salah satu pihak. Dari segi pelaku akad jual beli berbagi menjadi tiga bagian yaitu lisan, perantaraan dan perbuatan, akad jual beli yang dilakukan dengan lisan diganti dengan isyarat karena isyarat merupakan pembawaan alami dalam menampakan kehendak.Akad jual beli melalui perantara sama halnya dengan Ijab Qabul denagan ucapan misalnya pos dan giro. Jual beli inidilakukan antara penjual dan pembeli tidak berhadapan dalam satu majelisakad tapi melalui pos dan giro. Jual beli seperti ini diperbolehkan menurut syara'.

Jual beli dengan perbuatan atau dikenal dengan istilah Mu'athah yaitu mengambil dan memberikan barang tanpa Ijab dan Qabul, seperti seseorang mengambil merokok yang label harga sudah dituliskan label harga nya, dibandrol oleh penjual dan kemudian diberikan uang pembayarannya kepada penjual. Jual beli dengan cara demikian dilakukan tanpa Sighat Ijab Qabul antara penjual dan pembeli, menurut sebagian Syafiyah tentu hal ini dilarang sebab Ijab Qabul sebagai rukun jual beli tetapi sebagian Syafiyah lainnya seperti Imam Nawawi membolehkan jual beli barang kebutuhan sehari-hari dengan cara demikian, yakni tanpa Ijab dan Qabul terlebih dahulu. ${ }^{15}$ Jual beli yang dilarang dan batal hukum nya adalah barang yang dihukumkan najis oleh agama, seperti anjing, berhala, bangkai, khamar. Jual beli sperma hewan, seperti mengawinkan seekor domba jantan dengan betina agar dapat memperoleh keturunan. Jual beli anak binatang yang masih berada dalam perut induknya jual beli seperti ini dilarang, karena barangnya belum ada dan tidak tampak.

${ }^{13}$ Abdul Aziz Muhammad Azzam, Fiqh Muamalat Sistem Transaksi Dalam Fiqh Islam, (Jakarta: Amzah 2010), hlm. 23.

${ }^{14}$ Ibid., hlm. 76.

${ }^{15}$ Hendi Suhendi, Fiqh Muamalah, ( Jakarta: Rajawali Press 2010), hlm. 56. 
Jual beli dengan Muhaqallah ialah menjual tanaman-tanaman yang masih diladang atau disawah hal ini dilarang agama sebab ada persangkaan riba didalamnya. ${ }^{16}$ Jual beli dengan Mukhadharah yaitu menjual buah-buahan yang belum pantas untuk di panen, seperti menjual rambutan yang masih hijau, mangga yang masih kecil-kecil dan yang lainnya. Jual beli seperti ini samar-samar atau tidak jelas, Sabda Nabi Saw: "Dari anas bin malik r.a bahwa Rasullah saw melarang menjual buah-buahan sehingga tampak dan matang" (Bukhari Muslim ). Jual beli dengan Mulamasah yaitu jual beli secara secara sentuh menyentuh misalnya seseorang menyentuh sehelai kain dengan tangannya diwaktu malam atau siang hari maka orang yang menyentuh berarti telah membeli kain tersebut. Hal ini dilarang agama karena mengandung tipuan dnan kemungkinan akan menimbulkan kerugian dari salah satu pihak. Jual beli dengan Munabadzah yaitu jual beli secara lempar, melempar seperti seseorang berkata lemparkan kepada ku apa yang ada padamu, nanti ku lemparkan pula kepada mu apa yang ada padaku. Setelah terjadi lempar-melempar terjadilah jual beli hal ini dilarang karena mengandung tipuan dan tidak ada Ijab dan Qabul. Jual beli dengan Muzabanah yaitu menjual buah yang basah dengan buah yang kering, seperti menjual padi kering dengan bayaran padi basah sedangkan ukuran nya dengan dikilo sehingga akan merugikan pemilik padi kering. ${ }^{17}$

Jual beli yang dilarang dalam Islam sangat banyak, jumhur ulama sebagaimana di singgung diatas, tidak membedakan antara Fasid dan batal. Dengan kata lain, menurut jumhur ulama, hukum jual beli terbagi menjadi dua, yaitu jual beli shahih dan jual beli fasid, sedangkan menurut ulama Hanafiyah jual beli terbagi menjadi tiga jual beli shahih, fasid, dan batal.Berkenaan dengan jual beli yang dilarang dalam Islam , Wahbah Al-juhalili meringkasnya sebagai berikut. ${ }^{18}$

a. Jual beli orang gila. Ulama fiqih sepakat bahwa jual beli orang gila tidak sah.

b. Terlarang sebab ahliah atau ahli Akad. Ulama telah sepakat bahwa jual beli dikategorikan shahih apabila dilakukan oleh orang yang baligh, berakal, dapat memilih dan mampu bertasharuf secara bebas dan baik.mereka yang dipandang tidak sah jual belinya adalah sebagai berikut:

c. Jual beli anak kecil. Ulama fiqih sepakat bahwa jual beli anak kecil belum Mumayyiz dipandang tidak sah, kecuali dalam perkara-perkara yang ringan atau sepele menurut ulama Syafi'ah jual beli anak kecil yang belum baliq,tidak sah sebab tidak ada ahliah. ${ }^{19}$

Ulama fiqih juga telah sepakat atas sah jual beli yang didasarkan pada keridhoan diantara pihak yang melakukan akad, ada kesesuaian diantara Ijab dan Qabul, berada disatu tempat dan tidak terpisah oleh suatu pemisah.Jual beli yang tidak memenuhi ketentuan tersebut dipandang tidak sah. Beberapa jual beli yang dipandang tidak sah atau masih diperdebatkan oleh ulama adalah sebagai berikut:

a. Jual beli Mu'athah yaitu jual beli yang disepakati oleh pihak akad, berkenaan dengan barang maupun harganya, tetapi tidak memakai Ijab Qabul.

b. Jual beli melalui surat atau melalui utusan. Tempat berakad adalah sampainya surat atau urusan dari aqid pertama kepada aqid kedua. Jika Qabul melebihi tempat, akad tersebut dipandang tidak sah, seperti surat tidak sampai ketangan yang dimaksud.

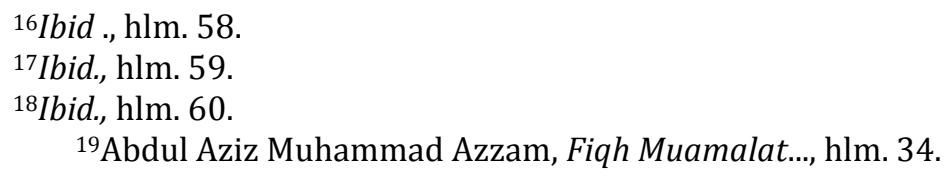


c. Jual beli dengan isyarat dan tulisan. Apabila isyarat tidak dapat dipahami dan tulisannya jelek tidak dapat dibaca akad tidak sah.

d. Jual beli barang yang tidak ada tempat

e. Jual beli tidak bersesuian antara Ijab dan Qabul

f. Jual beli Munjiz, yaitu jual beli Munjiz adalah yang dikaitkan dengan suatu syarat atau ditangguhkan pada waktu yang akan datang.

Secara umum, Ma'qud alaih adalah harta yang dijadikan alat pertukaran oleh orang yang berakad.Ulama fiqih sepakat bahwa jual beli dianggap sah apabila Ma'qud alaih adalah barang yang tetap atau bermanfaat, berbentuk, dapat diserahkan, dapat dilihat oleh orang-orang yang berakad,tidak bersangkutan dengan milik orang lain, dan tidak ada larangan dari syara'. ${ }^{20}$

Ada beberapa masalah yang disepakati oleh sebagian ulama tapi diperselisihkan oleh ulama lain sebagai berikut :

a. Jual beli benda yang tidak ada atau dikhawatirkan tidak ada

b. Jual beli barang yang tidak dapat diserahkan Jual beli yang tidak dapat diserahkan, seperti burung yang ada diudara atau ikan yang ada diair tidak berdasarkan ketetapan syara'.

c. Jual beli gharar adalah jual beli barang yang mengandung kesamaran, yaitu sesuatu yang tidak terang rupa dan sifatnya seperti menjual burung di udara, ikan dalam air, dan sebagainya yang dilarang oleh syara'. Menurut Ibnu Jazi AlMaliki, gharar yang dilarang ada 10 macam yaitu:

1. Tidak dapat diserahkan, seperti menjual anak hewan yang masih dalam kandungan induknya.

2. Tidak diketahui barang dan harga

3. Tidak diketahui sifat barang dan harga

4. Tidak diketahui ukuran barang dan harga

5. Tidak diketahui masa yang akan datang

6. Menghargakan dua kali pada satu barang

7. Menjual barang yang diharapkan selamat

\section{Jual Beli Produk Tupperware dan Hukumnya}

Tupperware adalah nama merek terkenal dari peralatan rumah tangga yang terbuat dari plastik, termasuk didalamnya untuk wadah penyimpanan, wadah penyajian, dan beberapa peralatan dapur yang diperkenalkan pada masyarakat umum pada tahun 1946. Mereka merancang, membuat, dan menyebarkan produknya keseluruh dunia melalui perusahaan induknya Tupperware Brands Corporation dan dipasarkan dengan metode penjualan langsung yang dikenal dengan julukan Indenpendent Sales Force yang saat ini 1,9 orang tersebar diseluruh Indonesia. ${ }^{21}$ Tupperware pertamakali dibuat pada tahun yang dibuat oleh Earl Tupper 1907-1983 di Amerika. Ia membuat suatu wadah plastik yang dipergunakan di rumah tangga untuk menyimpan makanan dan membuatnya kedap udara, salah satu yang terpenting dari produk ini adalah seal penyekatnya yang dikenal dengan sebutan Burping Seal yang merupakan ciri khusus yang terkenal dari produk tupperware yang membuatnya sangat berbeda dengan produk plastik sejenisnya.Tupperware mengawali strategi penjualan langsung

${ }^{20}$ Ibid., hlm 35.

${ }^{21} \mathrm{Http}: / /$ Sejarahtupperware.co.id, akses 6 Desember 2015. 
dengan Tupperware party. ${ }^{22}$ Orang yang mengenalkan strategi ini yaitu Bronie Wise pada tahun 1913- 1992, sebelum nya adalah seorang agen penjualan dari Stanley Home Product. Diawal tahun 1950 penjualan meledak dan membuatnya dikenal oleh banyak orang, hal ini terutama pengaruh dari Bronie Wise pada para wanitayang menjajakan tupperware dengan memakai metode party. Tupperware mulai dikenal pada masa perang II, dimana wanita dianjurkan untuk lebih memilih waktu untuk keluarganya dan dengan menjadi agen tupperware menjadikan mereka memiliki penghasilan sendiri dirumah selain itu ada tradisi yang dikenal dengan sebutan Assembly, yang diadakan disetiap distributor tupperware secara rutin. Tradisi ini diperkenalkan hingga saat ini sebagai sarana untuk memberi penghargaan kepada para penjual, perekrut terbaik untuk individu maupun secara team dan organisasi.

Tupperware menyebar kedaratan Eropa sejak kurun waktu 1960 ketika Mila Pond mengadakan sebuah Tupperware Party di WeybridgeInggris, serta beberapa kota lainnya. Namun pada tahun 2003, tupperware menutup operasinya di Inggris Raya, dikarenakan kekecewaan para penggunanya atas metode penjualan lansungnya dan baru di buka kembali pada tahun 2005 setelah ada restruksi. Rexall membeli saham tupperware pada tahun 1958, Rexall menjual toko obat-obatan tahun 1977 dan kemudian dinamakan menjadi Dart Industries, Dart Meger dengan Kraftco dan akhirnya membentuk perusahaan dengan nama Dart, sebelumnya dinamakan menjadi Premark International. Tupperware Brands kemudian dipecah dari Premark pada tahun 1996, kemudian Premark diakuisisi oleh Illinois Tool Works tiga tahun kemudian. Saat ini tupperware sudah terjual hampir 100 negara diseluruh dunia. ${ }^{23}$

Produk Tupperware adalah peralatan rumah tangga yang terbuat dari plastik murni. Tupperware berupa wadah penyimpanan sayuran, kue dan lain-lain, produk yang diproduksi dengan kualitas tinggi dibandingkan produk plastik lainnya. Proses pembuatan yang cermat menghasilkan produk yang berkelas dan telah melewati pemeriksaan kualitas yang ketat dilengkapi garansi seumur hidup.

Tupperwaremerupakan perusahaan multinasional yang memasarkan wadah yang terbuat dari plastik berkualitas premium termasuk didalamnya wadah penyimpanan, penyajian dan peralatan dapur lainnya.Jumlah produk tupperware kira-kira 1.200 produk dan berbagai macam tipe. Tipe termoset adalah jenis plastik yang tidak bisa didaur ulang atau dicetak lagi, pemanasan ulang akan menyebabkan kerusakan molekul-molekulnya, contoh: peralatan makan dari melanin, isolator, stop kontak dan lainnya. ${ }^{24}$ Termoplastik adalah jenis plastik yang bisa di daur ulang atau di cetak lagi dengan proses pemanasan ulang. Contoh: bahan pembungkus makanan, kantong plastik, botol dan yang lainnya. Garansi Perkembangan dunia perdagangan yang semakin pesat membuat produsen berlomba-lomba untuk memberikan pelayanan yang terbaik bagi para konsumen, Salah satu pelayanan yang diberikan adalah dengan memberikan layanan garansi. ${ }^{25}$ Garansi adalah perjanjian yang harus di pertanggungjawabkan oleh penjual terhadap pembeli dan harus ada kesepakatan antara kedua belah pihak atau lebih, didalam membuat suatu perjanjian barang yang dijual bebas dari

\footnotetext{
${ }^{22} \mathrm{Http}: / /$ Sejarahtupperware.co.id/pages/ list produk Akses 26 Agustus 2015.

${ }^{23} \mathrm{Http}: / / \mathrm{T}$ upperware co.id, akses 26 Agustus 2015.

${ }^{24} \mathrm{Http}: / /$ Tupperware.co.id/Pages/list Produk Akses Tanggal 26 Agustus 2015.

${ }^{25}$ Bermawi Iskandar, Manajemen Garansi Produk..., hlm.41.
} 
kecacatan atau kerusakan ${ }^{26}$.Pengertian lain garansi adalah surat keterangan dari suatu produk bahwa pihak produsen menjamin produk tersebut bebas dari kesalahan pekerjadan kegagalan bahan dalam jangka waktu tertentu biasanya pelanggan sebagai pengguna terakhir dan penjual melengkapi pengisian data pada surat keterangan tersebut untuk kemudian dikirim keprodusen agar didaftarkan tanggal mulai periode garansi. ${ }^{27}$

Menurut Mujiatun Ridawati dalam tulisannya, garansi merupakan "salah satu bentuk pelayanan yang diberikan penjual kepada pembeli sebagai pemenuhan terhadap hak-hak pembeli". 28 mengenai ketentuan-ketentuan garansi merupakan kesepakatan antara kedua belah pihak dalam perjanjian garansi biasanya tercantum dalam perjanjian surat garansi yang diberikan kepada pembeli, dalam perjanjian garansi kewajiban yang harus dilakukan oleh penjual adalah menanggung barang yang cacat yang dijual dan tidak diketahui oleh pembeli,karena pembeli mempunyai hak melakukan transaksi, hak dan kewajiban antara penjual dan pembeli dalam perjanjian garansi diatur dalam undang-undang No.8 tahun 1999 tentang perlindungan konsumen.

Pada umumnya garansi bertujuan untuk memberikan perlindungan pada konsumen apabila produk tidak sesuai dengan harapan, garansi merupakan hal penentuan keputusan untuk membeli atau tidaknya suatu produk yang ditawarkan. Produsen mau pun konsumen mendapatkan mamfaat garansibagi konsumen garansi melindungi dari pembelian produk yang cacat, bagi produsen garansi membatasi klaim yang tidak rasional dari konsumen. Disamping itu produsen dapat memanfaatkan garansi sebagai alat promosi yang efektif karena produk dengan masa garansi lebih lama memberikan sinyal bagi konsumen bahwa produk tersebut memiliki kualitas yang lebih baik. ${ }^{29}$ Garansi terdapat tiga bagian yaitu: Garansi replecement, Garansi servis, dan Garansi spare part.

Garansi seumur hidup adalah garansi penuh dari produsen bahwa produsen akan memperbaiki atau mengganti barang yang menjadi objek jual beli karena adanya cacat atau kerusakan pada barang yang dijual tanpa biaya.Indonesia adalah salah satu negara yang warga nya menjalan kan bisnis atau usaha dengan menciptakan sebuah produk dan menambahkan label garansi, pada saat ini produk-produk yang menggunakan label garansi sangat banyak terutama pada produk elektronik, hampir semua produk elektronik mempunyai label garansi akan tetapi apabila label garansi itu diberikan pada produk plastik seperti alat-alat rumah tangga akan lebih menarik konsumen untuk membelinya salah satu produk plastik menyelenggarakan garansi seumur hidup adalah tupperware. ${ }^{30}$

26Peter Salim, Kamus Bahasa Indonesia Kontemporer,(Yogyakarta:Modern English Press, edisi Pertama: 1991),hlm.443.

${ }^{27}$ Https://id.wikipedia.org/wiki/Garansi Akses 05 Juli 2015 .

${ }^{28}$ Http://ridaings.wordpress.com/2012/07/19/konsep khiyar aib dan revelensinya dengan garansi akses 7 april 2014

${ }^{29}$ Bermawi Iskandar, Manajemen Garansi Produk..., hlm. 43.

30Peter Salim, Kamus Bahasa..., hlm.16. 


\section{Hukum Islam tentang Jual Beli Tupperware Bergaransi Seumur Hidup}

Perusahaan tupperware telah memberikan buku atau katalog kepada member untuk menjual produk tersebut dengan harga yang telah dicamtum masing-masing produk dengan strategi pemasaran yang memberikan discon sebesar 30\% untuk reseller atau member. Wawancara dengan Mardiana bagian administrasi selaku karyawan di PT. Nazila Jambi Nugraha menjelaskan bahwa ${ }^{31}$ dengan strategi pemasaran ini maka seseorang tertarik untuk menjualnya, karena terkadang tidak semua reseller memberi discon 23\% terkadang 20\% dan bahkan 15\% kepada konsumen agar mendapat keuntungan yang lebih, tentunya para konsumen mencari member terbaik. Cara pemasaran tupperware yang tidak dimiliki produk plastik lainnya yaitu garansi seumur hidup tanpa batas waktu, hal ini membuat produk yang relatif mahal tertutupi akan pemasaran yang seperti itu karena proses pemakaian bisa seumur hidup. Proses pengambilan barang nya cepat, sehingga konsumen tidak mengeluh karena produk yang telah dibayar lunas tetapi barangnya lama sekali datangnya. ${ }^{32}$

Ada 3 cara pemasaran produk tupperware sebagai berikut: Jaringan sosial, Pemasaran online, dan menjadi pihak tema atau strategi unik pemasaran tupperware dengan demo rumah kerumah, bentuk pemasaran ini bersifat santai dan menyenangkan karena dilakukan dengan suasana santai dan seru. Selain dijual dan dipasarkan ditoko yang ingin memesantupperwaredapat memesan melalui sebuah tupperware party.

Dalam pelaksanaan jual beli produk tupperware, produsen memberikan jaminan garansi seumur hidup kepada konsumen. Akan tetapi produsen tidak memberikan garansi secara tertulis. melainkan garansi secara lisan. Berikut ini prosedur garansi seumur hidup: Konsumen harus membawa produk yang akan diklaim di kantor distributor, dengan catatan produk harus lengkap dan utuh. Staf distributor akan meneliti apakah barang yang di klaim masuk dalam ketentuan garansi seumur hidup. 1) jika iya, di tentukan apakah barang masuk kategori penggantian defektif regular atau produk di katalog tupperware saat ini atau non regular tidak ada di katalog atau barang regular yang stoknya kosong. 2) jika tidak, staf distributor memberika penjelasan kepada konsumen tentang penggantian defektif regular dan non regular dan lainnya. ${ }^{33}$

Ketentuan garansi seumur hidup barang. Barang yang rusak akan diganti kecuali produk meleleh, terkena api atau benda yang sangat panas seperti wajan atau penggorengan; Noda, makanan tertentu meninggalkan bekas atau noda pada produk namun tidak mempengaruhi fungsinya; Bekas gigitan, produk rusak terkena gigitan sehingga menimbulkan kerusakan; Tersayat, produk tersayat pisau atau benda tajam lainnya tapi tidak mempengaruhi fungsinya; Melengkung, produk terkena panas yang kuat untuk jangka waktu lama sehingga memuai atau melengkung; Pecah karena pukulan, produk pecah atau terkena pukulan benda keras.

Adapun hasil wawancara peneliti dengan konsumen tupperware dengan Ibu Murlia mengatakan bahwa: "saya membeli produk tupperware karna saya

${ }^{31}$ Wawancara Bersama Mardiana, Bagian Administrasi di PT. Nazila Jambi Nugraha Tanggal 21 Juli 2015.

32Wawancara Bersama Indrani, Bagian Sales Adminisrasi di PT. Nazila Jambi Nugraha, Tanggal 20 September 2015.

33http:// lifewaranti. Com akses .8 Desember 2015 
dijanjikan garansi seumur hidup oleh penjual, sejauh ini saya menggunakan produk ini tidak merasa di rugikan, selain produknya di kenal oleh masyarakat, juga mempunyai manfaat yang luar biasa. Apabila produk terjadi kerusakan kami dapat mengembalikan produk dan mendapat ganti nya yang baru lagi" 34

Pandangan hukum Islam terhadap jual beli produk tupperware yang bergaransi seumur hidup ini dengan demikian dibolehkan, karna konsumen tidak merasa dirugikan. walaupun produsen tidak memberikan garansi tertulis, tetapi memberi penjelasan secara lisan kepada konsumen tentang garansi seumur hidup. Apabila terjadi kerusakan konsumen harus membawa produk yang akan di klaim dikantor distributor dengan catatan produk harus lengkap dan utuh dan staf distributor akan meneliti barang yang di klaim apakah masuk dalam ketentuan garansi seumur hidup atau tidak, jika iya, ditentukan apakah barang masuk kategori produk yang ada dikatalog saat ini atau barang yang stoknya kosong. Jika tidak, barang yang rusak diganti dengan produk yang sama kemudian diserahkan kepada konsumen. Proses ini sudah baik dan sesuai firman Allah dalam surah AnNisa ayat 29 "Hai orang-orang yang beriman, janganlah kamu saling memakan harta sesamamu dengan jalan yang batil, kecuali dengan jalan perniagaan yang berlaku dengan suka sama-suka di antara kamu. Dan janganlah kamu membunuh dirimu; sesungguhnya Allah adalah Maha Penyayang kepadamu". 35

Berdasarkan Fatwa Dewan Syariah Tentang Pedoman Penjualan Langsung Syariah (PLBS) pula, telah disebutkan bahwa penjual barang dan produk jasa dengan menggunakan jejaring pemasaran atau pola penjualan berjenjang termasuk didalamnya Multilevel Marketing telah dipraktikkan oleh masyarakat. Berdasar firman Allah SWT, antara lain dalam Al- Baqarah (2) : 275 dan surat AnNisa(68) : 29, serta surat Al-Maidah (5), maka penjualan langsung berjenjang adalah cara penjualan barang atau jasa melalui jaringan pemasaran yang dilakukan oleh perorangan atau badan usaha secara kepada sejumlah perorangan atau badan usaha lainnya secara berturut-turut. Jika terjadi perselisihan diantara para pihak, maka penyelesaiannya dilakukan berdasarkan peraturan perundang-undang yang berlaku dan sesuai prinsip syariah.

\section{Penutup}

Dari apa yang telah penulis uraikan dalam pembahasan penelitian ini mengenai Sistem Jual Beli Produk Tupperware yang Bergaransi Seumur Hidup Menurut Hukum Islam di PT. Nazila Jambi Nugraha dapat disimpulkan sebagai berikut: pertama, praktek jual beli produk Tupperware yang bergaransi seumur hidup oleh PT. Nazila Jambi Nugraha dibolehkan. Apalagi perusahaan tupperware telah memberikan buku atau catalog kepada member untuk menjual produk tersebut dengan harga yang telah dicantumkan, dan perusahaan telah menyediakan lokasi atau tempat yang strategis untuk member yang ingin mengorder barang yang sesuai dengan pesanan konsumen. Konsumen juga tidak merasakan dirugikan walaupun produsen tidak memberi garansi tertulis tetapi memberi penjelasan secara lisan antara pihak produsen kepada konsumen mengenai pemberian garansi seumur hidup. Kedua, adanya dampak positif bagi penjual dan pembeli produk tupperware yaitu mendapatkan keuntungan dan meningkatkan

${ }^{34}$ Wawancara Bersama Ibu Murlia Member Tupperware di PT. Nazila Jambi Nugraha Tanggal 8Desember 2015.

${ }^{35}$ Q.S Al-An-Nisa (68) : 29. 
perekonomian masyarakat menjadi lebih baik, sehingga masyarakat bisa mendapatkan penghasilan melalui bisnis ini dengan penghasilan yang lumayan besar dan menciptakan lapangan pekerjaan baru untuk masyarakat. Bagi pembeli, pembeli mendapatkan mamfaat dan keunggulan dari produk tupperware. []

\section{BIBLIOGRAFI}

Al-Quran dan Terjemahannya

Abdul Rahman Ghazaly, Fiqh Muamalat, Jakarta: Kencana, 2010.

Abdul Aziz Muhammad Azzam, Fiqh Muamalat, Jakarta: Amzah 2010.

Bermawi P. Iskandar, Manajemen Garansi Produk dan Perkembangannya di Indonesia, Penelitian Fakultas Teknologi Industri, Institut Teknologi Bandung.

Djazuli, Ilmu Fiqh Penggalian Perkembangan dan Penerapan Hukum Islam, Jakarta : Kencana 2010.

Gemala Dewi, Hukum Perikatan Islam Indonesia, Jakarta: Kencana Pranada Media Group, 2006.

Hendi Suhendi, Fiqh Muamalah, Jakarta: Rajawali Press, 2010.

Ismail Nawawi, Fiqh Muamalah dan Kontemporer, Bogor: Ghalia Indonesia, 2012

Joko Subagyo, Metode Peneltian dalam Teori dan Praktek, Jakarta: Rineka Cipta, 2011.

Koentjaraningrat, Metode-metode Penelitian Masyarakat, Jakarta: PT. Gramedia, 1977.

Mustofa, Hukum Islam Kontemporer, Jakarta: Sinar Grafika, 2009.

Muhammad Idrus, Metode Penelitian Ilmu Sosial, Yogyakarta: PT. Aksara Pratama, 2009.

Suharsimi Arikunto, Prosedur Penelitian, Jakarta: PT. Rineka Cipta 1998.

Soedharyo Soimin, Kitab Undang-undang Perdata, Jakarta: Sinar Grafika, 2010.

Sugiyono, Metode Penelitian Kuantitatif dan Kualitatif $R$ dan D, Bandung: Alfabeta, 2013.

Sayuti Una, Pedoman Penulisan Penelitian, Fakultas Syariah IAIN STS Jambi Syariah Press, 2012.

Samsul Anwar, Hukum Perjanjian Syariah, Jakarta: Rajawali press, 2010.

Taufiq Hidayat, Garansi dan Penerapannya Perspektif Hukum Islam, Bandung: Almawardi, 2006.

Tim penyusun, Pedoman Penulisan Penelitian Fakultas Syariah, Jambi Syariah Press, 2010.

UU. NO.8 Tahun 1999 Tentang Perlindungan Konsumen. 